\title{
How 1-Methylcyclopropene Has Altered the Washington State Apple Industry
}

\author{
James P. Mattheis ${ }^{1}$ \\ USDA, ARS Tree Fruit Research Laboratory, 1104 North Western Avenue, Wenatchee, WA 98801
}

Additional index words. controlled atmosphere storage, decay, fruit quality, internal breakdown, lenticel breakdown, superficial scald, SmartFresh, watercore

\begin{abstract}
Commercialization of 1-methylcyclopropene (1-MCP) has provided a new tool to storage operators for management of fruit quality in the postharvest environment. For apple as an example, availability of the commercial 1-MCP product SmartFresh has brought an additional dimension to decisions regarding postharvest chemical treatments, storage temperature regimes, storage atmospheres, and planned storage duration based on fruit maturity at harvest. Poststorage impacts of 1-MCP use at harvest on handling and packing procedures have also become apparent with commercial use. Marketing programs have also been impacted because the "tails of the manifest" (large/small sizes, lower color grades) can be held longer in cold storage after packing primarily as a result of slower loss of firmness in many cultivars. Although some quality issues, primarily related to physiological disorders occurring on specific cultivars, are yet to be fully resolved, continuing widespread use of 1-MCP is indicative of its commercial usefulness.
\end{abstract}

Identification of 1-methylcyclopropene (1-MCP) as a potent inhibitor of ethylene action (Sisler and Blankenship, 1996; Sisler and Serek, 1997) has provided the plant science research community with a valuable tool with which ethylene biology can be studied. Additionally, inhibition of ethylene action modulates the pattern of climacteric fruit ripening (Watkins, 2006). For apple, impacts of 1-MCP treatment are consistent with a number of commercial postharvest goals related to fruit quality maintenance and avoidance of physiological disorders. Commercialization of 1-MCP as SmartFresh by AgroFresh has provided another tool for postharvest management of apple fruit. This technology has been widely adopted in a relatively short period of time in the domestic apple industry and its use has resulted in a number of anticipated as well as unanticipated consequences on operations from production and harvest in the field through marketing of packed fruit. In an effort to characterize these results, the Washington state apple industry was used as a model to determine what industry practices have or have not been altered after the availability of this product. Conversations with growers, warehouse management and marketing personnel, and research and extension personnel were the basis for the following information.

In recent years, the total value of apples produced in Washington State has approached \$1 billion (National Agricultural Statistics Service, U.S. Department of Agriculture [NASS, USDA], 2005). This industry focuses on marketing intact, high-quality whole fruit, although a large processing industry also exists in Washington State. Additionally, the volume of apples processed into ready-to-eat apple slices is increasing. Total apple production in Washington State in 2004 was $\approx 5.9$ billion pounds (NASS, USDA, 2005). The logistics of handling and marketing a crop volume of this magnitude present many commercial challenges at and before har-

\footnotetext{
${ }^{1}$ To whom correspondence should be addressed; e-mail mattheis@tfrl.ars.usda.gov.
}

vest as well as during and after storage and packing. Although 1-MCP is currently applied only in the postharvest environment, indirect impacts of its use on preharvest practices and poststorage packing and marketing are evident.

\section{PRE- AND AT-HARVEST IMPACTS OF 1-METHYLCYCLOPROPENE}

The Washington state apple industry has in recent years experienced considerable change as a result of market forces that reflect increased worldwide supply of fresh apples, changes in consumer preference for cultivars, and other economic pressures related to costs of production and financing. As supplies have increased, the market for lowerquality fruit in terms of size and color grade has decreased. This change has created a need for warehouses to encourage growers to focus on production and harvest of fruit that meets market demands for higher fruit quality. Growers are being encouraged to leave poorly colored, off-size fruit in the field to reduce the impact this fruit has on the storage and handling processes in the warehouse. When successful, a grower's delivered tonnage may decrease, but decreased costs of storage and packing can compensate for the loss of potential revenue.

The availability of SmartFresh treatment at the warehouse has increased the need for accurate information from the field regarding fruit condition and maturity. Minimizing the volume of fruit that is treated with SmartFresh and subsequently culled or sent for processing enhances the economics of SmartFresh use. Apples with a maturity suitable for long-term controlled atmosphere (CA) storage have responded well to commercial SmartFresh use, and maturity suitable for long-term $\mathrm{CA}$ as defined by various maturity indices varies with cultivar. A need to anticipate the volume of fruit arriving at the warehouse to be treated with SmartFresh is based in part on scheduling the application with AgroFresh because company personnel are required to perform the treatment. Application of a postharvest treatment by non- warehouse personnel is in fact a new practice in the Washington State industry.

Another impact of postharvest 1-MCP use is the potential to eliminate postharvest drench treatments for control of superficial scald and decay. Where the fungicide drench is not used, a renewed emphasis on field decay control programs, both preharvest fungicide application and field sanitation, has developed with the availability of SmartFresh.

\section{IMPACTS OF \\ 1-METHYLCYCLOPROPENE ON WAREHOUSE PROCEDURES AT HARVEST}

The decision to use SmartFresh is based on fruit maturity information as well as warehouse experience with cultivars and marketing objectives. As a result of these two factors, considerable variation in cultivar-specific postharvest practices exists within this industry. On arrival at the packing house, in-house assessments of fruit maturity indices are also conducted to determine what type and duration of storage are appropriate for individual lots. Maturity indicators, including starch index, firmness, and peel color, are typically monitored to assess whether apples should be stored in air or CA storage and for what duration. The presence of watercore in susceptible cultivars also contributes to decisions related to storage type and duration as well as conditions of storage (temperature, $\mathrm{O}_{2}$ and $\mathrm{CO}_{2}$ concentrations). The need for accurate fruit maturity information at harvest has increased because the additional decision of treatment with SmartFresh is also based in part on this data. For example, 'Golden Delicious' apples that have starch and firmness values appropriate for long-term CA may or may not be treated depending on peel color. Inhibition of ethylene action can delay degreening (Dauny and Joyce, 2002; Fan and Mattheis, 1999; Pre-Aymard et al., 2003; Zanella, 2003). Some warehouses do not use SmartFresh on 'Golden Delicious' with green peel color at harvest as a result of the risk of having fruit 
with market-limiting green peel color during the mid to late (March to July) marketing period. The presence of watercore, a flooding of tissues near the fruit core with sorbitol-rich translocate (Marlow and Loescher, 1984), may also limit the use of SmartFresh because 1-MCP treatment can delay the dissipation of watercore (Mattheis, unpublished data). Watercore can lead to an increased risk of internal browning (Faust et al., 1969); therefore, practices that prolong the presence of watercore during storage are considered to be undesirable.

Management options to minimize two postharvest problems, superficial scald (scald) and decay, have expanded as a result of the availability of SmartFresh. A widely practiced means of scald control for many years has been a prestorage drench with the antioxidant diphenylamine (DPA; Smock, 1957). A fungicide is usually also included in this drench solution. Effective scald control can also be obtained after 1-MCP treatment (Fan and Mattheis, 1999; Rupasinghe et al., 2000; Watkins et al., 2000); therefore, many warehouses have opted to use SmartFresh for scald control and to limit the use of the DPA/ fungicide drench or to drench only with a fungicide. Although the use of DPA and fungicides has decreased as a result of SmartFresh availability, drench treatments have not been eliminated as a result of situations in which the use of SmartFresh alone is not viewed as sufficient for scald control or as a result of 1-MCP's lack of fungicidal activity.

A large proportion $(50 \%$ to $75 \%)$ of the total apple crop in Washington State is stored in CA. Development of this infrastructure has also served as a means to apply SmartFresh because CA storage rooms must be gas-tight to operate efficiently. Although incorporating SmartFresh treatment has not required extensive new construction or modification of existing facilities, operation of rooms has changed as a result of the impacts of 1$\mathrm{MCP}$ on fruit ripening. Set points for temperature, $\mathrm{O}_{2}$, and $\mathrm{CO}_{2}$ during $\mathrm{CA}$ storage that maximize fruit quality responses and minimize risk of disorder development differ with cultivar and are subject to change as storage technologies improve (Kupferman, 2003). Some storage operators have altered CA conditions based on the reduced rates of fruit ripening after 1-MCP treatment. In particular, higher $\mathrm{O}_{2}$ and temperature set points have been used in some warehouses, but widespread adoption of these changes has not yet occurred. The use of higher $\mathrm{O}_{2}$ and higher temperature has been practiced to lower risk of low $\mathrm{O}_{2}$ or low-temperature injuries. In general, achieving and maintaining lower set points for temperature, $\mathrm{O}_{2}$, and $\mathrm{CO}_{2}$ causes operational expenses to increase. Although the industry is interested in practices that reduce energy use and the costs of storage, reduced energy use has not as yet been the driving force for changes in storage parameters. Another change in CA operations after the availability and use of SmartFresh includes opening and resealing CA rooms to remove individual orchard lots. This tempo- rary break in the CA is typically of short ( 1 to 5 d) duration, and some warehouses have used this practice successfully to pack and market individual lots to optimize quality or fulfill market demands. In Washington State, this practice was not typical before the availability of SmartFresh.

\section{IMPACTS OF 1-METHYLCYCLOPROPENE ON MANAGEMENT OF WATERCORE AND LENTICEL BREAKDOWN}

Some changes in storage practices for individual cultivars have also occurred as a result of the use of SmartFresh. For 'Delicious' and 'Fuji', two cultivars that are prone to development of watercore, SmartFresh provides another choice in the existing options for storage management. Watercore in these cultivars produced in Washington State can have different implications for storage management. For 'Delicious', the presence of watercore often occurs when fruit maturity is past the optimum for longterm CA storage. As such, a state grade standard is in place that prohibits export of watercored 'Delicious' apples any time and sales of Washington extra fancy or fancy grade fruit to the domestic market if watercore is present after $1 \mathrm{Feb}$. of the year after production (Washington Administrative Code). Lack of ethylene action can delay the clearing of watercore, so some warehouses with watercored fruit scheduled for export soon after harvest, or for storage past January, have opted to not treat with SmartFresh. Some warehouses have opted to treat watercored fruit with SmartFresh and then store fruit in air rather than CA. Another option has been to store SmartFresh-treated watercored fruit at higher ( $2 \%$ to $3 \%) \mathrm{O}_{2}$ concentrations until watercore has cleared and then reduce $\mathrm{O}_{2}$ concentration to $1 \%$ to $1.5 \%$. In 'Fuji' apples, watercore is typically present when in fruit harvested at optimum maturity for longterm storage. The presence of watercore in 'Fuji' apples increases the risk of development of internal browning during CA storage (Argenta et al., 2002). The SmartFresh use recommendations for 'Fuji' include a $10-\mathrm{d}$ delay between harvest and SmartFresh application. This period is typically not long enough to dissipate watercore, but is sufficient to fully cool fruit and lower $\mathrm{CO}_{2}$ production compared with fruit at harvest. 'Fuji' apples are not subject to the 'Delicious' watercore-related grade standard, but because watercore increases the risk for internal disorder development during CA, some warehouses have chosen to store SmartFresh-treated 'Fuji' apples in air rather than CA. By using this protocol, a number of warehouses have avoided internal disorder development and maintained marketable quality through the intended 5- to 7-month marketing period.

Commercialization of 1-MCP was preceded by extensive research from academic, government, and industry scientists. Although some results contraindicating the use of
1-MCP in specific situations were identified before commercialization, the variability of responses to $1-\mathrm{MCP}$ used in a commercial environment was difficult to simulate. For example, lenticel breakdown after storage of 'Gala' apples has been an ongoing issue in Washington State for a number of years. After the introduction of SmartFresh, some warehouses reported an increase in incidence of this disorder. Research with 'Gala' before 1-MCP commercialization did not indicate a link between development of lenticel breakdown and 1-MCP. In fact, lenticel breakdown is typically not observed unless apples are subjected to actual or simulated conditions of packing. Although the disorder typically develops only after fruit has been packed, not all warehouses experience the problem to the same degree. The incidence of lenticel breakdown in Washington State warehouses has varied considerably implicating handling and packing line conditions as contributing factors (Eric Curry, personal communication). Other causal factors include fruit maturity at harvest, storage type, and storage duration. As a result of the large variation in both pre- and postharvest management between growers and warehouses, it has been difficult to determine to what degree the use of SmartFresh $^{\text {SM }}$ has contributed to development of this disorder.

Controlled studies conducted by Eric Curry (unpublished data) have not demonstrated a clear relationship between the use of SmartFresh and development of the disorder; however, the spectrum of warehouse-specific procedures occurring throughout the industry is difficult to simulate. The use of SmartFresh has allowed many warehouses to store 'Gala' longer, and the likelihood of disorder development increases with increased storage duration. Many warehouses have instituted a number of changes to attempt to reduce incidence of the disorder, including improved harvest management, altering packing line conditions, and changing or reducing postharvest chemical use. All of these changes can contribute to a reduced risk of lenticel breakdown and also have been incorporated in many warehouses as a means to continue to use SmartFresh despite its possible role in disorder development. The desire to continue to use SmartFresh as a result of its impact on edible quality management was specifically mentioned by many warehouse personnel even as they continue to determine whether SmartFresh use contributes to development of lenticel breakdown.

\section{1-METHYLCYCLOPROPENE AS A TOOL FOR MANAGING FRUIT QUALITY}

The impacts of 1-MCP on quality retention have resulted in many changes in packinghouse and marketing operations. The packed size and grade combinations in Washington State can exceed 60 within an orchard lot, making inventory management a critical factor impacting profitability. Although premium grades and sizes typically are in high 
demand, marketing of the remaining grade/ size combinations is critical to maximizing returns to the grower. Before the availability of SmartFresh, the packed inventory from CA rooms needed to be sold in a relatively short time period to avoid excessive ripening and loss of fruit quality while fruit were held in air. The pressure to move packed inventory often resulted in diminished financial returns, particularly for lower grades and extremely large and small fruit. Because SmartFreshtreated fruit ripens more slowly during storage in air after CA compared with nontreated fruit, the pressure has decreased to sell packed inventory in a short time period to avoid quality deterioration. This extension of the marketing period has contributed to better financial returns and many warehouses feel it is a critical part of the value of SmartFresh to the industry. The longer ripening period after storage has also allowed some warehouses to access distant export markets where the time previously needed to transport fruit was too long to allow delivery of high-quality fruit.

The availability of 1-MCP as SmartFresh has changed operations during apple fruit production, storage, and marketing in Washington State. This material provides an additional tool for managing fruit quality that can allow replacement or modification of existing practices. Although SmartFresh technology has been rapidly adopted within the Washington State apple industry, most industry personnel feel much remains to be learned as to its usefulness within commercial operations.

\section{Literature Cited}

Argenta, L.C., X. Fan, and J.P. Mattheis. 2002. Impacts of watercore on gas permeance and incidence of internal disorders in 'Fuji' apples. Postharvest Biol. Tech. 24:113-122.

Dauny, P.T. and D.C. Joyce. 2002. 1-MCP improves storability of 'Queen Cox' and 'Bramley' apple fruit. HortScience 37:1082-1085.

Fan, X. and J.P. Mattheis. 1999. Development of apple superficial scald, soft scald, core flush, and greasiness is reduced by MCP. J. Agr. Food Chem. 47:3063-3068.

Faust, M., C.B. Shear, and M.W. Williams. 1969 Disorders of carbohydrate metabolism of apples (watercore, internal breakdown, low temperature and carbon dioxide injuries). Bot. Rev. 35:168-194.

Kupferman, E. 2003. Controlled atmosphere storage of apples and pears. Acta Hort. 600: 729-735.

Marlow, G.C. and W.H. Loescher. 1984. Watercore. Hort. Rev. (Amer. Soc. Hort. Sci.) 6:189251.

National Agricultural Statistics Service, U.S. Department of Agriculture. 2005. Washington state agricultural statistics. 23 Aug. 2006. $<\mathrm{http}$ :// www.nass.usda.gov/Publications/Ag_Statistics/ agr05/05_ch5.PDF>.

Pre-Aymard, C., A. Weksler, and S. Lurie. 2003. Responses of 'Anna', a rapidly ripening sum- mer apple, to 1-methylcyclopropene. Postharvest Biol. Technol. 27:163-170.

Rupasinghe, H.P.V., D.P. Murr, G. Paliyath, and L. Skog. 2000. Inhibitory effect of 1-MCP on ripening and superficial scald development in 'McIntosh' and 'Delicious' apples. J. Hort. Sci. Biotechnol. 75:271-276.

Sisler, E.C. and S.M. Blankenship. 1996. Methods of counteracting an ethylene response in plants. US Patent No. 5518988.

Sisler, E.C. and M.E. Serek. 1997. Inhibitors of ethylene response in plants at the receptor level: Recent developments. Physiol. Plant. 100:577-582.

Smock, R.M. 1957. A comparison of treatments for control of the apple scald disease. Proc. Amer. Soc. Hort. Sci. 69:91-100.

Washington Administrative Code 16-403-290. Damage from invisible watercore. 23 Aug. 2006. $<\mathrm{http}$ ://search.mrsc.org/nxt/gateway.dll?f= templates\&fn=legpage.htm\$vid=rcwwac:leg $>$.

Watkins, C.B. 2006. The use of 1-methylcyclopropene (1-MCP) on fruits and vegetables. Biotechnol. Adv. 24:389-409.

Watkins, C.B., J.F. Nock, and B.D. Whitaker. 2000. Responses of early, mid and late season apple cultivars to postharvest application of 1 methylcyclopropene (1-MCP) under air and controlled atmosphere storage conditions. Postharvest Biol. Technol. 19:17-32.

Zanella, A. 2003. Control of apple superficial scald and ripening-A comparison between 1-methylcyclopropene and diphenylamine postharvest treatments, initial low oxygen stress and ultra low oxygen storage. Postharvest Biol. Technol. 27:69-78. 